\title{
Preparation of total RNA from a very small wheat embryo suitable for differential display
}

\author{
By YIHUA CHEN ${ }^{1}$, SONG WEINING ${ }^{2 * *}$ and GRANT DAGGARD ${ }^{1 *}$
}

\author{
${ }^{1}$ Department of Biological and Physical Sciences, The University of Southern Queensland, Toowoomba, \\ Queensland 4350, Australia \\ ${ }^{2}$ Leslie Research Centre, Queensland Department of Primary Industries, Toowoomba, Queensland 4350, \\ Australia
}

(Accepted 9 May 2003; Received 21 February 2003)

\begin{abstract}
Summary
A simple method was developed for extracting total RNA from a single mature wheat seed embryo, which is very small and hard. Guanidine thiocyanate and chloroform were employed and the grinding of the samples was performed in a microcentrifuge tube with a plastic pestle. A "jacket" of liquid nitrogen and simplified procedures were applied to ensure the thorough grinding of the embryo tissue and to minimise the loss of samples. These measures substantially increased the recovery of total RNA in the extraction process. Reliable differential display was successfully achieved with the total RNA after DNase treatment and reverse transcription. This method makes it viable to study gene expression and gene regulation in a single wheat seed embryo. It may also give researchers the ability to analyse mRNAs in tissues or organs which were previously too small for RNA isolation using conventional procedures.
\end{abstract}

Key words: Total RNA, single wheat embryo, differential display, reverse transcription

\section{Introduction}

The expression of many genes may be differentially regulated in response to the change of environmental elements, developmental stages, chemical treatment and genotypes. Analysis of gene expression is very important in biological studies (White, 2001). The difficulty of isolating RNA from a small amount of tissue is an obstacle to the analysis of gene expression. For example, the analysis of gene expression associated with dormancy and its breakage in a wheat embryo is of very important agronomic interest, because this breakage may relate to pre-harvest sprouting which damages the quality of grains (Derera, 1993). Dormancy and its breakage are very sensitive to many factors and the condition of the seeds, some of which are indistinguishable, such as the maturity of seeds and any injury to the seed coat. In order to monitor the possible bias caused by the variation in seed condition, it is necessary to analyse individual seed embryos besides the analysis of pooled embryos. There are many available protocols for extracting RNA from different plant materials, but large amounts of tissues are required (Wadsworth et al., 1988; Vicient \& Delseny, 1999). There is no method available for extracting RNA from a wheat embryo. A wheat embryo is very small $(600 \mu \mathrm{g})$ and hard. For such small material, a high yield RNA isolation method is essential for obtaining sufficient RNA. Effective lysis of the cells and minimum sample loss are crucial for such a method. It has been reported that total RNA can be isolated from a small piece of human eye tissue (several milligrams). The eye tissue was homogenised in extraction buffer, and a silica gel binding technique was used to isolate total RNA (Gonzalez et al., 1999). However, it is impossible to homogenise a hard wheat embryo well in extraction buffer. It is also difficult to grind a wheat embryo in liquid nitrogen. The frozen embryo tissues may quickly melt during grinding, or boiling liquid nitrogen may cause sample loss. In order to solve this problem, we designed a liquid nitrogen "jacket" to ensure the thorough grinding of an embryo into a fine powder. In the subsequent extraction, we utilised guanidine thiocyanate, which has been widely applied for RNA isolation (Maniatis et al., 1989; Puissant \& Houdebine, 1990), and adopted an ethanol precipitation procedure to collect the RNA. We simplified the procedures of the available methods (Maniatis et al., 1989) to minimise the RNA loss and obtain purified DNA-free total RNA from a single wheat embryo. The RNA was suitable for differential display reverse transcription PCR (DDRT PCR), which is a useful method in gene expression analysis (Liang \& Pardee, 1992; Liang et al.,1994). 


\section{Materials and Methods}

\section{General}

Pipette tips, tubes, plastic pestle and MilliQ water were treated with diethyl pyrocarbonate (DEPC) (Sigma, St. Louis, USA) and autoclaved. Guanidine thiocyanate (4 M) (Sigma, St Louis, USA) solution and $800 \mathrm{ml}$ litre $^{-1}$ ethanol were made with DEPC treated and autoclaved MilliQ water.

\section{Plant materials}

Mature seeds of two spring wheat varieties, which differ in their susceptibility to pre-harvest sprouting, AUS1408 (resistant) and Cascades (susceptible), were used to provide a source of embryo material.

\section{Sample preparation}

A single wheat seed was separated, by using a sterile scalpel blade. The embryo was isolated under a dissecting microscope and placed in a polypropylene $1.5 \mathrm{ml}$ centrifuge tube filled with liquid nitrogen. To provide a cooling jacket during the grinding process, a $5 \mathrm{ml}$ polypropylene tube (Sarstedt, Ingle Farm, SA, Australia) was fixed in a foam plastic block, and filled with liquid nitrogen. The $1.5 \mathrm{ml}$ centrifuge tube containing an embryo was then placed into this tube and the liquid nitrogen in both tubes was replenished, until it no longer boiled. The embryo was ground into a fine powder using a pre-chilled disposable pellet pestle (Kontes, Vineland, NJ, USA).

\section{Total RNA extraction}

After the embryo sample was fully ground, the tube was allowed to warm up to room temperature. A total RNA isolation buffer of $600 \mu 1$, containing $488 \mu 14$ M guanidine thiocyanate, $12 \mu 12$ mercaptoethanol (ICN Biomedical, Aurora, Ohio, USA) and $100 \mu$ l chloroform was freshly prepared. Initially, $100 \mu \mathrm{l}$ RNA isolation buffer was added to the ground embryo material and the plastic pestle was used to ensure that a homogenised suspension was formed. Subsequently, the remaining total RNA isolation buffer $(500 \mu \mathrm{l})$ was added and used to rinse the material remaining on the pestle into the tube. The solution in the tube was mixed and left at room temperature for about $30 \mathrm{~min}$. The tube was then centrifuged at $16100 \mathrm{~g}$ for $10 \mathrm{~min}$ and the supernatant was transferred into a new tube. $1 \mathrm{ml}$ absolute ethanol was added to the supernatant and, following mixing, placed at $-20^{\circ} \mathrm{C}$ for $2 \mathrm{~h}$. The tube was then centrifuged at $16100 \mathrm{~g}$ for $10 \mathrm{~min}$ and the supernatant discarded. The pellet was washed twice with $200 \mu 1800 \mathrm{ml}$ litre $^{-1}$ ethanol and allowed to dry briefly, following which $42 \mu 1$ of DEPC treated MilliQ water was added and the solution was stirred with a pipette tip to assist in re-dissolving the pellet. Finally, the tube was centrifuged at $16100 \mathrm{~g}$ for 5 min and the supernatant transferred to a new tube for DNase treatment.

\section{DNase treatment and analysis}

RQ1 RNase Free DNase (Promega, Madison, WI, USA) was used to treat the RNA sample. To a $42 \mu 1$ sample of the total RNA solution, $5 \mu 110 \times$ RQ1 DNase Reaction Buffer, $2 \mu 1$ RQ1 DNase (one unit $\mu^{\mathrm{l}^{-1}}$ ) and $1 \mu \mathrm{l}$ RNasin (Promega, Madison, WI, USA) (35 unit $\mu \mathrm{l}^{-1}$ ) were added and mixed. The tube was incubated at $37^{\circ} \mathrm{C}$ for $15 \mathrm{~min}$. Then $100 \mu 1 \mathrm{DEPC}$ treated MilliQ water and $150 \mu \mathrm{l}$ chloroform were added to the mixed solution and the tube centrifuged at $16100 \mathrm{~g}$ for $10 \mathrm{~min}$. After centrifugation, the aqueous phase was carefully transferred to a new tube and $150 \mu 1$ DEPC treated MilliQ water was added to the remaining chloroform. The centrifugation was repeated and the two aqueous supernatants were pooled. Two volumes of absolute ethanol were then added to the supernatant and mixed. The tube was placed at $-20^{\circ} \mathrm{C}$ for $2 \mathrm{~h}$, followed by centrifuging at $16100 \mathrm{~g}$ for $10 \mathrm{~min}$. The pellet was washed with $800 \mathrm{ml}$ litre $^{-1}$ ethanol twice. After a brief drying, the pellet was dissolved in $10 \mu \mathrm{l}$ DEPC treated MilliQ water. Finally, the integrity of extracted RNA was assessed by agarose (15 $\left.\mathrm{mg} \mathrm{ml} \mathrm{m}^{-1}\right)$, MOPS, formaldehyde, gel electrophoresis (Maniatis et al., 1989). The total RNA sample $(2 \mu \mathrm{l})$ was mixed with $1 \mu \mathrm{l} 6 \times$ bromophenol blue dye prior to loading. The RNA bands were displayed by using an ethidium bromide stain. The yield of total RNA was measured with a spectrophotometer Ultrospec 4050 (LKB Biochrom, Cambridge, England) at a wavelength of $260 \mathrm{~nm}$.

\section{Reverse transcription}

M-MLV Reverse Transcriptase (RTase) (Promega, Madison, WI, USA) was used to synthesise the cDNA. The reaction included: $5 \mu 1$ total RNA treated with DNase, $2 \mu 1100 \mu \mathrm{M}$ anchor primer T14A (custom primer, Invitrogen Australia, Mulgrave, Vic, Australia), 200 units M-MLV RTase, $1 \times$ M-MLV RT Buffer, $2 \mu \mathrm{dNTPs}$ (10 mM each) (Invitrogen, Carslbad, CA, USA) and 35 units RNasin. Initially anchor primers, total RNA and water were mixed and placed at $70^{\circ} \mathrm{C}$ for $5 \mathrm{~min}$ and then transferred immediately to ice for $2 \mathrm{~min}$. A pre-mixed solution of the other components of the reaction was then added to make a total volume of $25 \mu 1$. The reaction was incubated at $37^{\circ} \mathrm{C}$ for $1 \mathrm{~h}$ followed by heating at $65^{\circ} \mathrm{C}$ for $10 \mathrm{~min}$.

\section{$D D R T P C R$}

Red Hot ${ }^{\circ}$ DNA polymerase (ABgene, Epsom, Surrey, UK) was used for the PCR. The $20 \mu \mathrm{l} \mathrm{PCR}$ reaction contained $1 \times$ PCR Buffer IV, $1.5 \mu \mathrm{M} \mathrm{MgCl}_{2}$, $200 \mu \mathrm{M}$ dNTPs, $250 \mathrm{nM}$ primer T12AA (custom primer, Invitrogen Australia, Mulgrave, Vic., 
Australia). $250 \mathrm{nM} \mathrm{10-mer} \mathrm{random} \mathrm{primer} \mathrm{OPD-08}$ (Operon, Alameda, CA, USA) and 1 unit Red Hot ${ }^{\circledR}$ DNA polymerase. The cDNA was diluted 1:2, with autoclaved MilliQ water and $2.5 \mu 1$ was used in each PCR reaction. PCR was performed using a PTC160TM Programmable Thermal Controller (MJ Research, Watertown, MA, USA). The solution was denatured at $94^{\circ} \mathrm{C}$ for $2 \mathrm{~min}$, and then subjected to the following temperature profile: $94^{\circ} \mathrm{C}$ for $30 \mathrm{~s}$, $40^{\circ} \mathrm{C}$ for $1 \mathrm{~min}, 72^{\circ} \mathrm{C}$ for $35 \mathrm{~s}$ in 40 cycles and finished with a $72^{\circ} \mathrm{C}$ extension for $5 \mathrm{~min}$. DDRTPCR products were separated by non-denaturing polyacrylamide gel electrophoresis and visualised by silver staining (Bassam et al., 1991). The $60 \mathrm{ml}$ gel system included $12 \mathrm{ml}$ acrylamide-bis (Ultra pure grade, Amresco, Solon, Ohio, USA), $6 \mathrm{ml} 10 \times \mathrm{TBE}$, $600 \mu \mathrm{l}$ ammonium persulfate solution $\left(100 \mathrm{mg} \mathrm{ml}^{-1}\right)$ and $60 \mu 1 \mathrm{~N}, \mathrm{~N}, \mathrm{~N}^{\prime}, \mathrm{N}^{\prime},-$-Tetramethylethylenediamine (TEMED) (ICN Biotechnologies, Aurora, Ohio, USA)

\section{Results}

Agarose gel electrophoresis of DNase treated total RNA displayed the presence of both 28S rRNA and $18 \mathrm{~S}$ rRNA, with the $28 \mathrm{~S}$ rRNA band being almost twice as intense as the 18S rRNA band in all the samples (Fig.1A). This indicates that the method is reliable and the total RNA was not significantly degraded during the extraction and DNase treatment. Approximately $5 \mu \mathrm{g}$ of total RNA was extracted from a single wheat embryo. The $\mathrm{A}_{260} / \mathrm{A}_{280}$ ratio was 1.9. Half of the DNase treated total RNA was used for reverse transcription. The synthesised cDNA could be used for about 30 DDRT PCR reactions. The DDRT PCR products of individual wheat embryos of different varieties are shown in Fig.1B. When the cDNA was replaced with a DNase treated total RNA in DDRT PCR, no amplification product was detected (data not shown).

\section{Discussion}

The success of the RNA extraction from a small embryo to a great extent depends on the thorough grinding of the embryo tissue. It is essential that the embryo should be frozen completely throughout the whole grinding process. Any extra addition of liquid nitrogen during grinding could cause splashing and result in sample loss. The use of a liquid nitrogen "jacket" substantially reduced the rate of evaporation and sample loss caused by splashing during the grinding process. Furthermore, the $5 \mathrm{ml}$ tube is a suitable size for holding the $1.5 \mathrm{ml}$ tube for grinding. This device is easy, effective and reliable for the grinding of all kinds of small tissues using liquid nitrogen. It is also important to minimise the loss of the small quantity of samples during the extraction
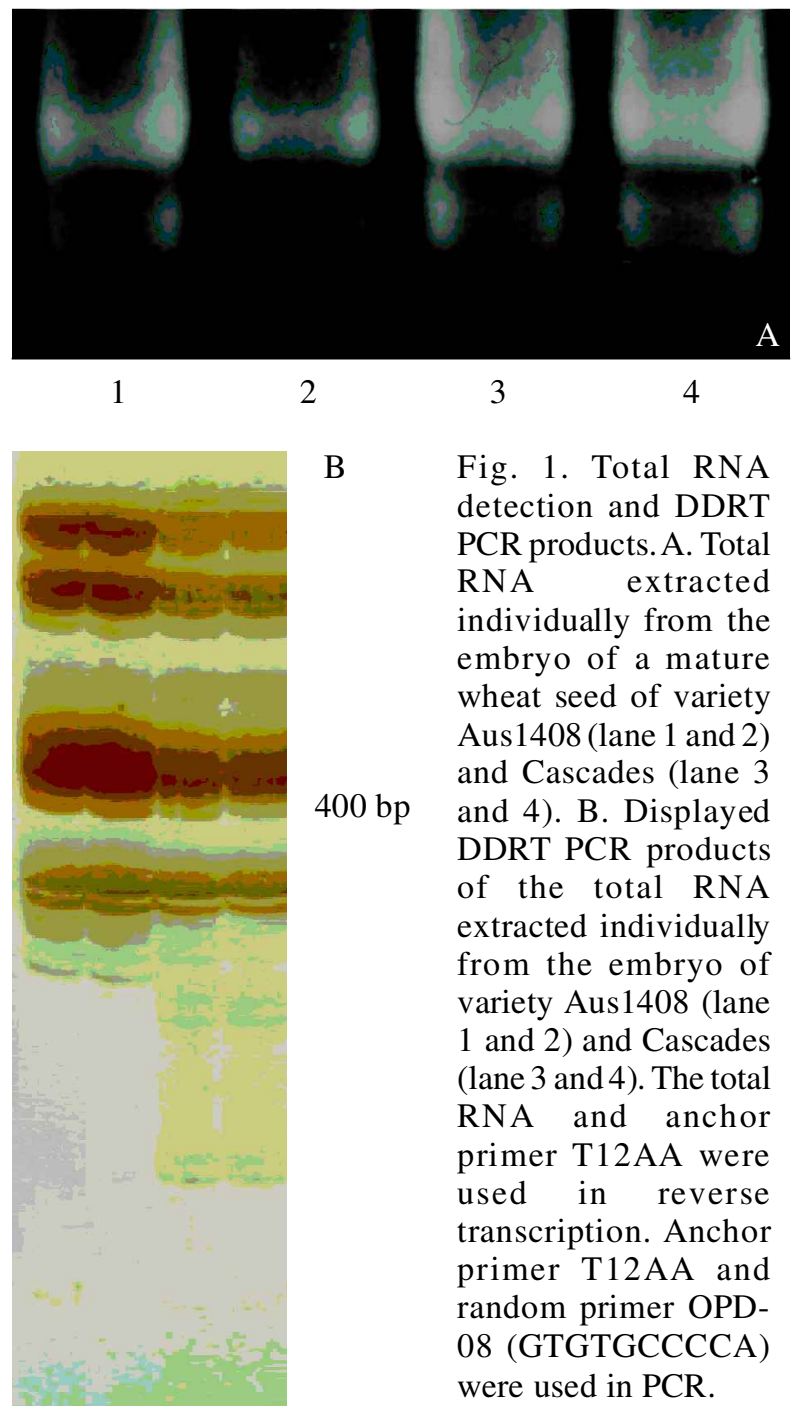

$200 \mathrm{bp}$

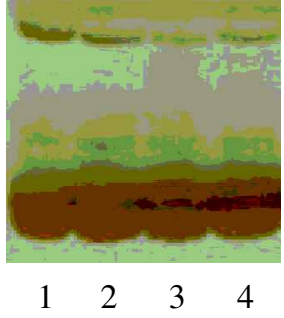

and purification process. There are many commercial kits for isolating RNA using different techniques, but DNase treatment and subsequent purification is still needed for RNA samples isolated by using most of the kits. Therefore, we adopted an inexpensive method using ethanol precipitation to collect total RNA from the extraction buffer followed by DNase treatment. In order to reduce the sample loss, purification was performed only once. The total RNA 
precipitated from the extraction buffer was washed with $800 \mathrm{ml}$ litre $^{-1}$ ethanol prior to DNase treatment, which was followed by the purification procedure. The isolated total RNA was shown to be pure enough and free of DNA for subsequent differential display. This method is simple, inexpensive and no special equipment is required. It can be used for gene expression analyses in wheat embryos, such as in our study on gene expression associated with dormancy. It may also facilitate many other gene expression studies using small amounts of tissue.

\section{Acknowledgements}

This research was supported by an Australian Research Council (ARC) SPIRT grant. We are grateful to Dr Mandy Christopher (Leslie Research Centre, Farming Systems Institute, QDPI) for her critical reading of the manuscript.

\section{References}

Bassam B J, Caetano-Anolles G, Gresshoff P M. 1991. Fast and sensitive silver staining of DNA in polyacrylamide gels. Analytical Biochemistry 196:80-83.
Derera N F. 1993. The effects of preharvestrain. In Preharvest Field Sprouting in Cereals, pp. 3-14. Ed. N F Derera. Boca Raton, Florida: CRC Press.

Gonzalez P, Samuel Zigler J Jr, Epstein D L, Borrás T. 1999. Identification and isolation of differentially expressed genes from very small tissue samples. BioTechniques 26:884-892.

Liang P, Pardee A B. 1992. Differential display of eukaryotic messenger RNA by means of the polymerase chain reaction. Science 257:967-971.

Liang P, Zhu W, Zhang X, Guo Z, O'Connell R P, Averboukh L, Wang F, Pardee A B. 1994. Differential display using one base anchored ologo-dT primers. Nucleic Acids Research 22:5763-5764.

Maniatis T, Fritsch E F, Sambrook J. 1989. Molecular Cloning, A Laboratory Manual, pp. 7.19-7.45. Cold Spring Harbor, NY: Cold Spring Harbor Laboratory Press.

Puissant C, Houdebine L M. 1990. An improvement of the single-step method of RNA isolation by acid guanidinium thiocyanate-phenol-chloroform extraction. Bio Techniques 8:148-149.

Vicient C M, Delseny M. 1999. Isolation of total RNA from Arabidopsisthaliana seeds. Analytical Biochemistry 268:412413.

Wadsworth G J, Redinbaugh M G, Scandalios J G. 1988. A procedure for the small-scale isolation of plant RNA suitable for RNA blot analysis. Analytical Biochemistry 172:279-283.

White R J. 2001. Gene Transcription: Mechanisms and control, pp. 1-25. Oxford, UK: Blackwell Science. 